\title{
INCLUSIVE EDUCATIONAL REALITY OFFERING THE PLACE FOR THE ACCEPTANCE OF DIVERSITY OF CLASSROOMS THROUGH THE PRISM OF PEDAGOGICAL PRACTICE
}

\section{[INKLUZIVNA EDUKACNA REALITA PONUKAJUCA PRIESTOR PRE AKCEPTACIU DIVERZITY SKOLSKEJ TRIEDY CEZ PRIZMU PEDAGOGICKEJ PRAXE]}

\author{
Renata Polakovicova
}

DOI: 10.18355/PG.2015.4.1.2-24

\begin{abstract}
The ideal of inclusive education in past decades has become the main idea of the education system all over the world. And it is precisely because the inclusive education allows the development of all students, including students with the physical, psychological and social barriers in their own development. The aim of the author is in the present study bring the scientific information about inclusive educational reality. Information come from research from the field of teaching practice in the Slovak Republic. The inspiration was the existing heterogeneity of students, which is becoming in various forms an essential feature of inclusive schools. The author of the scientific work deals with questions of the relationship between respecting the principles of inclusion in the educational process and quality level of inclusion in a class where there are pupils with special educational needs. The study gives view of the determinants of respect for the principles of inclusion in educational practice and reciprocal linkage between the application of the principles of inclusion and satisfaction of pupils with special educational needs with life in the classroom. The same extent we wonder if the age of teacher determines the area of respect for the principles of inclusion in educational practice, but also a relationship between the length of teaching experience / individual years of ordinary schools / number of pupils per class / significant differences between boys and girls and the quality of compliance with conditions / principles / requests inclusion in the educational process.
\end{abstract}

\section{Key words}

inclusion, education, conditions, needs of pupils, teaching recommendations, teaching practice

\begin{abstract}
Anotácia
Ideál inkluzívneho vzdelávania sa $\mathrm{v}$ posledných desatročiach stal hlavnou ideou vzdelávacieho systému po celom svete vzhl'adom na to, že inkluzívne vzdelávanie umožňuje rozvoj všetkých žiakov, vrátane tých, ktorým vo vývine vlastného potenciálu bránia fyzické, psychické či sociálne prekážky. Ciel'om autorky je podat' prostredníctvom predkladanej vedeckej štúdie informácie o inkluzívnej edukačnej realite, ktoré vyústujú z výskumného šetrenia uskutočneného $\mathrm{v}$ teréne pedagogickej praxe v Slovenskej republike. Inšpiračnou tematikou bola existujúca heterogenita žiakov, ktorá sa stáva vo
\end{abstract}


svojich rôznych podobách základným rysom inkluzívnych škôl. Autorka sa vo vedeckej práci zaoberá otázkami vzájomného vzt’ahu medzi dodržiavaním princípov inklúzie vo výchovno-vzdelávacom procese a úrovňou kvality inklúzie v triede, v ktorej sa nachádza žiak (žiaci) so špeciálnymi výchovnovzdelávacími potrebami. Podaný je pohl'ad na determinanty rešpektovania princípov inklúzie vpedagogickej praxi či vzájomnú väzbu medzi uplatňovaním princípov inklúzie a spokojnost'ou žiakov so špeciálnymi výchovno-vzdelávacími potrebami so životom $\mathrm{v}$ triede. V rovnakej miere nás zaujímalo, okrem iného, nielen to, či vek učitel'a determinuje oblast' rešpektovania princípov inklúzie v pedagogickej praxi, ale i existencia vzt’ahu medzi dĺžkou pedagogickej praxe učitel'ov / jednotlivými ročníkmi bežných škôl / počtom žiakov v triede / signifikantnými medzipohlavnými rozdielmi medzi chlapcami i dievčatami a kvalitou dodržiavania podmienok / princípov / prístupov inklúzie vo výchovno-vzdelávacom procese.

\section{Kl'účové slová}

inkluzívna edukačná realita, podmienky, výchovno-vzdelávacie potreby žiakov, odporúčania pre pedagogickú prax

\section{Teoretické východiská rešpektovania diverzity žiackej populácie v medzinárodnom kontexte}

Diverzita predstavuje zdroj poznania heterogenity a determinantov rôznych javov a vo vzdelávaní je považovaná za zdroj nových príležitostí a inovácií orientovaných na dosahovanie efektívnejších výsledkov edukácie, či už v dimenzii osobných, individuálnych efektov alebo $\mathrm{v}$ dimenzii spoločenskej prosperity.

V európskom priestore sú vyvíjané mnohé iniciatívy, ktoré sa snažia o podporu rozmanitosti a rozvoj diverzifikovanej školskej populácie, prostredníctvom vytvárania a ponuky kvalitných edukačných programov, implementujúcich princípy inklúzie, ekvity, rešpektu, vzájomnosti a humanity. Súčast'ou projektovania optimalizovaných edukačných postupov je výskum diverzifikovanej školskej populácie a rozmanitosti edukačných potrieb, ktoré z nej plynú, s ciel'om podporit' kvalitu výchovy a vzdelávania (Duchovicova, 2013).

Snaha o rešpektovanie akýchkol’vek individuálnych potrieb vyplývajúcich z diverzity žiackej a študentskej populácie v bežných edukačných podmienkach smeruje $\mathrm{k}$ tvorbe a rozvíjaniu proinkluzívnej filozofie vzdelávania. Svetonázorové a konceptuálne východiská edukačnej diverzity ponúka monografické dielo G. Pintesa (2014), ktoré má ambíciu kompenzovat' nedostatok publikácii z oblasti filozofie výchovy, vd'aka ktorým si môže záujemca o edukačné vedy lepšie a komplexnejšie vytvorit’ prehl'ad o tých konceptoch, smeroch a prúdoch humanitných vied, ktoré v zásadnej miere ovplyvnili pedagogické myslenie $\mathrm{v}$ ostatných dvoch storočiach.

Potreba zaoberat' sa diverzitou detskej, žiackej a študentskej populácie vedukačnom výskume plynie zo základných princípov výchovy a vzdelávania v Slovenskej republike dotýkajúcich sa ekvity, zákazu všetkých 
foriem diskriminácie a obzvlášt' segregácie, so zohl'adnením výchovnovzdelávacích potrieb jednotlivca intaktného i výnimočného. Vytváranie rovnosti šancí $\mathrm{v}$ prístupe $\mathrm{k}$ vzdelaniu môže zásadným spôsobom ovplyvnit' kvalitu sociálnej inklúzie, a tým kvalitu života jednotlivcov v spoločnosti. I toto sú dôvody prečo patrí diverzita žiackej populácie $\mathrm{k}$ významným javom tvoriacim predmet skúmania pedagogickej vedy (Duchovicova, 2012). Diverzita $\mathrm{v}$ školských podmienkach predstavuje pochopenie a poznanie prepojenosti l'udskej kultúry a prírodného environmentu, neustále vyjadrovanie vzájomného rešpektu, učitel'ovu toleranciu, uvedomenie si toho, že osobná, kultúrna a inštitucionálna diskriminácia vytvára pretrvávajúce privilégiá len pre niektorých a neustále vytvára znevýhodnenia pre iných.

Školská populácia zahŕňa najrozmanitejšie skupiny žiakov, a to na rôznych stupňoch školskej dochádzky od predškolských zariadení (napr. Slezakova, 2008), po vysoké školy (napr. Seidler - Belikova - Dufekova, 2013; Kvetonova - Strnadova - Hajkova, 2012), ktoré sa stávajú v duchu humanistických tradícií internacionálnymi strediskami kultúry a vzdelanosti. Monografia Diverzita $\mathbf{v}$ edukácii je autorskou prácou riešitel’ov projektu VEGA č. 1/0184/11 s názvom Diverzita školskej populácie ako objekt pedagogickej vedy a východisko inovácií $\mathbf{v}$ súčasnej škole. Jednotlivé kapitoly monografie sú autorskou prácou riešitel'ov, pričom ich predmetom je analýza základných pojmov ako diverzita, inklúzia, diferenciácia, heterogenita, ekvita, globalizácia, školská trieda, kognitívna edukácia a metakognitívne stratégie, individuálna koncepcia vyučovania, špecifické poruchy učenia, začiatočné vyučovanie, štruktúrovanie textu, agresia v edukačnom prostredí, rodinné prostredie, kooperácia rodičov, učitelov a iných odborníkov v kontexte diverzity či pedagogická diagnostika.

Diverzita, ktorú nachádzame v našich školách, je často považovaná za výzvu vyžadujúcu iné, alternatívne spôsoby intervencie a organizácie edukačnej činnosti. Monografia spoluautorov J. Komora, R. Polakovicova (2013) zahŕňa potrebu exaktným skúmaním tejto problematiky prispiet' $\mathrm{k}$ riešeniu otázok, týkajúcich sa procesuálnej stránky vzdelávania $\mathrm{s}$ akcentom na rešpektovanie podmienok diverzity školskej triedy vkontexte inkluzívneho vzdelávania žiackej populácie a zároveň naznačit' určité možnosti zvyšovania kvality a celkovej efektívnosti vyučovacieho procesu. Súčasná diverzita školskej triedy si vyžaduje od učitel'a, aby sa zamýšl'al nad možnost’ami ako si zorganizovat' vyučovanie tak, aby každý žiak so svojimi individuálnymi potrebami dosiahol požadovaný učebný výkon spolu s osobnostným rozvojom.

Možnosti vystavat' školu tak, aby reagovala na žiacku diverzitu, ale nestratila pritom zo zretel’a kvalitu vzdelávania s riešením rozdielnosti skupinových a individuálnych charakteristík žiakov na jednej strane a záväzkom k rovným vzdelávacím príležitostiam $\mathbf{v}$ spoločnosti pluralitných hodnôt, zámerov, štandardov na druhej strane ponúka monografia od autoriek H. Kasikovej a J. Strakovej (eds.) (2011). Uvedenú problematiku dopíňa napr. monografia štúdií od V. Lechtu (ed.) (2012), ktorá má za ciel' preniknút' do oblasti inkluzívnej edukácie, ktorej teoretici i praktici doteraz často nevenovali patričnú pozornost', pričom ide o oblast' presahujúcu didaktické problémy súvisiace s inkluzívnou edukáciou. Knižné dielo L. Zilchera (2013) ponúka 
okrem terminologického vymedzenia i prierez histórie prístupu spoločnosti k jedincom s postihnutím, narušením a ohrozením (PNO), implementáciu konceptu inklúzie do hlavného vzdelávacieho prúdu či podmienky inklúzie jedincov s PNO. Hajkova V. a I. Strnadova (2010) sa zameriavajú na vzdelávacie potreby $\mathrm{v}$ inkluzívnom poňatí, sociálnu heterogenitu ako charakteristiku inkluzívnej školy, inkluzívne vzdelávanie i inkluzívne orientovanú diagnostiku a poradenstvo. Cenný je však i náhl’ad do inklúzie vo výskumných šetreniach či prípadové štúdie škôl.

Monografia Cesty k inklúzii je dielom autorského kolektívu P. Seidlera, V. Kurincovej, J. Komoru (2008), tvoreného tímom zahrnutým do výskumnej úlohy VEGA č. 1/3632/06 Cesty k inklúzii - východiská inkluzívnej pedagogiky a ich implementácia $v$ pedagogickej praxi $v$ kontexte novodobých trendov edukácie. Jej ciel'om bolo preskúmat' podmienky a determinanty efektívnej integrácie a úspešného uplatňovania filozofie inklúzie detí s postihnutím medzi intaktnú populáciu. Autori jednotlivých šestnástich predkladaných štúdií riešili konkrétne parciálne problémy spojené s otázkami integrácie a inklúzie žiakov s postihnutím alebo narušením. Monografia ponúka základný pojmový aparát $\mathrm{v}$ kontexte problematiky a rozpracováva konkrétne tematické okruhy, tvoriace integrálnu súčast’ širšej dimenzie tejto problematiky.

Spomínaní spoluautori P. Seidler a V. Kurincova (2005) vo svojom d’alšom literárnom diele Inakosti $\mathbf{v}$ edukačnom prostredí poukazujú na vzt’ah diferencovanej žiackej komunity, integrácie výnimočných žiakov do bežných škôl a na význam kooperácie $\mathrm{v}$ edukačnom prostredí. V tejto publikácii sa autori zameriavajú na etiológiu ,inakostí“, rozdielností medzi l'ud'mi a na ich vnútorné a vonkajšie príčiny. Na význame dodáva tejto publikácii i skutočnost', že okrem teórie prezentuje i príklady z praxe a rôzne názory dokumentuje výskumami našej i zahraničnej proveniencie.

Medzinárodné skúsenosti nájdeme v zahraničných literárnych zdrojoch napr. od autorov D. Stevens-Smith, M. Warner, M. Padilla (2014) zaoberajúcich sa pohl'adom na verejný vzdelávací proces vedúci $\mathrm{k}$ prepracovaniu programu prípravy učitel'ov. Za zmienku stoja i N. Hunt a K. Marshall (2012), ktorí pojednávajú o špeciálnej edukácii určenej všetkým det'om s výstrahou rizikových faktorov a včasnej intervencii potrebnej pri všetkých druhoch špeciálnych výchovno-vzdelávacích potrieb. Špeciálnymi vzdelávacími potrebami veurópskom kontexte $\mathrm{v}$ tematickej publikácii o politike a inkluzívnej praxi podporujúcej včasnú intervenciu na základe vhodnej depistáže sa zaoberajú C. Meijer, V. Soriano a A. Watkins (2003).

Podnetným je i zahraničný „sprievodca“ pre začínajúcich špeciálnych pedagógov od spoluautorov B. S. Billingsley, M. T. Brownell, M. Israel, M. L. Kamman (2013), v ktorom môžu záujemcovia o riešenú problematiku nájst' cenné informácie o špeciálnych vzdelávacích právach, spolupráci a kompenzácii edukátorov, ich organizácii a riadení vlastnej činnosti v triede, s nevyhnutnost'ou neustálej podpory svojich žiakov pomocou ich híbkového poznania a ovládania efektívnej praktiky plánovania hodín s limitmi schopností a možností žiakov so zdravotným znevýhodnením. 


\section{Empirické východiská úrovne hodnotenia podmienok inkluzívneho vzdelávania vzhl'adom na špeciálne výchovno-vzdelávacie potreby žiakov bežných škôl}

Pri koncipovaní výskumného problému a hlavného ciel'a výskumu sme vychádzali z uskutočnenia analýz doterajších výskumov, zo štúdia odbornej literatúry a tiež z našich predchádzajúcich empirických zistení. Na základe týchto poznatkov sme stanovili nasledovný výskumný problém:

„Aký je vzájomný vzt’ah medzi dodržiavaním princípov inklúzie vo výchovno-vzdelávacom procese a úrovňou kvality inklúzie v triede, v ktorej sa nachádza žiak (žiaci) so špeciálnymi výchovno-vzdelávacími potrebami?““

Hlavným ciel'om výskumného šetrenia bolo zistit', v akej miere sa rešpektuje diverzita žiakov a uplatňujú sa podmienky inkluzívneho vzdelávania vzhl'adom na špeciálne výchovno-vzdelávacie potreby výnimočných žiakov v rámci škôl bežného typu.

Vychádzajúc z uvedeného sme si stanovili nasledovnú hypotézu a v rámci nej pät' podhypotéz, ktorých platnost' sme overovali výskumom:

- H 1 Predpokladáme, že existuje priamo úmerná závislost' medzi dodržiavaním princípov inklúzie a úrovňou kvality inklúzie žiakov so špeciálnymi výchovno-vzdelávacími potrebami, to znamená, že čím viac sa budú uplatňovat' princípy inklúzie, tým bude vyššia spokojnost' žiakov so špeciálnymi výchovno-vzdelávacími potrebami so životom $\mathrm{v}$ triede a naopak.

- H 1.1 Predpokladáme, že vek učitel'a nedeterminuje oblast' rešpektovania princípov inklúzie v pedagogickej praxi.

- H 1.2 Predpokladáme, že existuje vzt'ah medzi dĺžkou pedagogickej praxe učitel'ov a dodržiavaním podmienok inklúzie vo výchovnovzdelávacom procese.

- H 1.3 Predpokladáme, že existuje vzt’ah medzi dodržiavaním princípov inklúzie vo vyučovaní a jednotlivými pozorovanými ročníkmi.

- H 1.4 Predpokladáme, že počet žiakov v triede sa premieta do úrovne akceptovania prístupov inklúzie vo výučbe.

- H 1.5 Predpokladáme, že nezistíme signifikantné medzipohlavné rozdiely, podla ktorých by sa mala významne líšit' kvalita podmienok inklúzie v triede medzi chlapcami a dievčatami.

Pri výbere výskumných metód sme ich vol'bu podriadili výskumným ciel'om a hypotézam výskumu. Pre dobrú orientáciu v skúmanej problematike sme využili literárnu metódu. V rámci získavania informácií sme použili metódy zamerané na získavanie nových empirických údajov, do ktorých spadajú nasledovné pozorovacie a exploračné metódy: metóda pološtruktúrovaného interview, metóda štruktúrovaného pozorovania a neštandardizovaný dotazník.

V našom výskume považujeme za najviac prínosnú metódu štruktúrovaného pozorovania žiakov a učitel'ov v ich prirodzených životných podmienkach. Pre účely nášho výskumu sme použili metódu štruktúrovaného pozorovania a uskutočnili sme následné mikrovyučovacie analýzy pozorovaných hodín. Vypracovali sme si pozorovaciu analytickú schému vyučovacej hodiny určenú na registráciu zaznamenaných údajov na 
vyučovacích hodinách v kategóriách javov: P (Prístupnost') - Výchovnovzdelávací proces prístupný všetkým žiakom, rešpektujúci ich jedinečnost' a rozmanitost'; A (Angažovanie) - Aktívne angažovanie sa žiakov vo vlastnom učení sa; O (Obohatenie) - Odlišnosti medzi žiakmi využívané ako zdroj, vzájomné obohatenie vyučovania a učenia; S (Sebahodnotenie) Sebadôvera, sebarealizácia a sebahodnotenie podporujúce výkon každého žiaka; Ú (Úlohy) - Domáce úlohy prispievajúce k učeniu všetkých žiakov. Jednu kategóriu tvorilo 5 pozorovaných javov, tzn. 5 kategórií javov zobrazovalo celkovo 25 pozorovaných javov.

V našom prípade sa pozorované javy dotýkali podmienok inklúzie uplatňovaných na výchovno-vzdelávacom procese $\mathrm{v}$ pozorovaných triedach so žiakmi intaktnými aj žiakmi so špeciálnymi výchovno-vzdelávacími potrebami. Priebeh činností sme sledovali na každej vyučovacej hodine osobne. Uskutočnili sme tak priame, komplexné, skupinové pozorovanie, pri ktorom sme boli $\mathrm{v}$ triede umiestnení tak, aby sme čo najmenej rušili pozorované osoby - žiakov.

K zberu dát sme využili d'alšiu metódu exploračného charakteru neštandardizovaný dotazník „Podmienky inklúzie vo výchovnovzdelávacom procese“. Dotazník bol zameraný na získanie údajov a postojov od respondentov vzt'ahujúcich sa $\mathrm{k}$ riešenej problematike. $\mathrm{V}$ rámci fázy získavania údajov sme využili neštandardizovaný dotazník vlastnej konštrukcie určený pre žiakov nižšieho sekundárneho vzdelávania realizovaného na II. stupni základnej školy, konkrétne 7. - 9. ročníkov základných škôl. Pri konštruovaní dotazníka sme vychádzali z parciálnych ciel’ov nášho výskumu. Štandardizáciu dotazníka sme nerealizovali.

Dotazník bol zameraný na zistenie toho, ako žiaci vnímajú svoje prostredie v triede. Bol rozdelený do nasledovných dimenzií: všeobecná spokojnost', učebná zát'až, interakcia učitel'a so žiakmi, vzt’ahy medzi dievčatami a chlapcami, úspech $\mathrm{v}$ škole, sociálna opora a fyzické prostredie učebne. Dotazník „Podmienky inklúzie vo výchovno-vzdelávacom procese“ pozostáva z 25 položiek. Dotazník na pätbodovej Likertovej škále meria pät' dimenzií: Ú (Úlohy), $\mathrm{P}$ (Prístupnost'), A (Angažovanie), $\mathrm{O}$ (Obohatenie), S (Sebahodnotenie), a to na stupnici od 5 „vždy“ po 1 „nikdy“. K jednotlivým položkám kategoriálnej škály sme priradili čísla, čím sme vytvorili číselnú (numerickú) posudzovaciu škálu. Celkové skóre dotazníka sa pohybuje v rozmedzí od 25 do 125 bodov. Validita nami skonštruovaného dotazníku bola zabezpečená dvomi odborníkmi z oblasti pedagogiky.

Pri spracovaní údajov získaných z výskumu pomocou štatistických metód sme uskutočnili štatistickú verifikáciu hypotéz výskumu. Využili sme deskriptívnu štatistiku, konkrétne popis charakteristiky polohy, ktorá slúži $\mathrm{k}$ stručnému a prehl'adnému popisu dát získaných výskumom. Využité boli kvantitatívne metódy - aritmetický priemer, modus, medián, variačné rozpätie, variačný rozptyl, smerodajná (štandardná) odchýlka, popisná štatistika, percentuálne výpočty, Pearsonov korelačný koeficient, Studentov t-test, test ANOVA i kvalitatívne metódy - logická analýza a syntéza, indukcia a dedukcia, komparácia.

Výsledky získané prostredníctvom kvantitatívnych a kvalitatívnych metód sme popisovali a interpretovali na základe našich teoretických vedomostí 
získaných štúdiom odbornej literatúry, našich doterajších empirických výsledkov a skúseností nadobudnutých v praxi.

Výskumnú vzorku tvorilo niekol'ko kategórií vzhl'adom na zvolené výskumné metódy, ktorú sme pre náš výskum získali dostupným výberom v spolupráci s niekol'kými vybranými učitel'mi základných škôl. Výskumnú vzorku tvorili vybrané základné školy, v ktorých sa na úrovni nižšieho sekundárneho vzdelávania vzdelávali žiaci intaktní aj žiaci so špeciálnymi výchovno-vzdelávacími potrebami na druhom stupni základných škôl. Výskumnú vzorku predstavovali nasledovné kategórie:

- Vyučovacie hodiny predmetov, obsahovo zameraných na osvojenie si základov vedných disciplín, resp. rôznych oblastí l'udskej činnosti, na druhom stupni základných škôl (7.-9. ročník) v Bratislavskom a Nitrianskom kraji, v rámci ktorých sme uskutočnili pozorovania $\mathrm{v} 15-$ tich triedach (pričom $\mathrm{v}$ jednej triede boli traja žiaci so špeciálnymi výchovno-vzdelávacími potrebami).

Charakterizovaním súboru podl'a ročníka zistíme, že v siedmom ročníku sa odpozorovalo $138(32,2 \%)$ vyučovacích hodín a ôsmy i deviaty ročník mali narovnako pozorovaných 145 (33,9 \%) vyučovacích hodín. V 15-tich triedach sme pozorovali spolu 428 vyučovacích, 45 minútových hodín (celkovo 15 týždňov). V jednej triede sme uskutočnili pozorovania najmenej 24 a najviac 31 vyučovacích hodín (celkovo 1 týždeň). Hospitovanie bolo realizované na rôznych vyučovacích predmetoch $\mathrm{z}$ dôvodu komplexnejšieho pozorovania.

- Učitelia všeobecno-vzdelávacích predmetov s rôznou dížkou pedagogickej praxe získaných dostupným výberom v Bratislavskom a Nitrianskom kraji. Boli to učitelia druhého stupňa základných škôl poskytujúcich nižšie sekundárne vzdelávanie v 7. - 9. ročníkoch.

Do skúmania boli začlenení učitelia s rôznou dížkou pedagogickej praxe, ktorých väššinu tvorili učitelia ženského pohlavia. Všetci mali ukončené vysokoškolské vzdelanie. Učitelia mali minimálne 1-ročnú prax a maximálne 44-ročnú prax, z čoho vychádza, že priemerná dížka pedagogickej praxe učitel'ov bola 22 rokov.

Z hl'adiska počtu rokov pedagogickej praxe učitel'ov sa výskumu zúčastnilo 63 učitel’ov vykonávajúcich svoju prax do 5 rokov, 58 učitel’ov praktikujúcich v rozmedzí 6 až 10 rokov, 76 učitel'ov učiacich $11-20$ rokov, 62 učitel'ov vykonávajúcich učitel'ské povolanie $21-30$ rokov a najviac 169 učitel'ov majúcich 31 a viacročnú prax.

Vnútorná diferencovanost' nášho výskumného súboru bola daná tiež vekovým zložením učitel'ov, konkrétne 9 učitel'ov mladších ako 25 rokov, 100 učitel'ov vo veku 26 - 35 rokov, 50 učitel'ov s vekovou kategóriou 36 45 rokov, 124 učitel'ov s vekom od 46 do 55 rokov a napokon s najväčším zastúpením 145 učitel'ov vo veku 56 rokov a viac. Hranica minimálneho veku učitel'ov je 24 rokov, maximálne dosiahnutý vek 65 rokov a aritmetický priemer vekového rozptylu učitel'ov je 47 rokov.

- Žiaci navštevujúci druhý stupeň základných škôl s nižším sekundárnym vzdelávaním v Nitrianskom a Bratislavskom kraji, konkrétne 7. - 9. ročník základných škôl, t.j. žiaci vo veku od 12 do 15 rokov. Ich výber bol zámerný, pretože pozorované triedy tvorili žiaci intaktní aj žiaci so 
špeciálnymi výchovno-vzdelávacími potrebami, kde ich v jednej triede bol počet 3 . Z toho vyplýva, že pri pozorovaniach v 15-tich triedach bol celkový počet žiakov so špeciálnymi výchovno-vzdelávacími potrebami 45.

Pri deskripcii súboru (žiakov) z hl'adiska ročníka, ktorý navštevovali, môžeme konštatovat', že siedmy a ôsmy ročník navštevovali žiaci v rovnakom počte $112(34,6$ \%) a v deviatom ročníku bolo o dvanást' žiakov menej, teda $100(30,9 \%)$.

Pri charakteristike žiakov podl'a pohlavia môžeme konštatovat', že výberový súbor spolu tvorilo 324 žiakov, z čoho bolo menej chlapcov oproti dievčatám, konkrétne išlo o 147 chlapcov (45,4 \%) a 177 dievčat (54,6 \%).

Charakteristika súboru podl'a veku vypovedá o tom, že minimálny vek žiakov je 11 rokov a maximálny vek 15 rokov. Priemerný vek žiaka je na vekovej hranici 13 rokov.

Konštatujeme, že naša výskumná vzorka nemôže byt' samozrejme považovaná za reprezentatívnu (bližšie vid'. R. Polakovicova, 2011; J. Komora, R. Polakovicova, 2013, s. 93-111).

Analýza a interpretácia vybraných výsledkov empirického výskumu

\section{A) Kritérium POHLAVIE v skóre dotazníka}

Rozdiely medzi žiakmi podl'a pohlavia (vid'. tabul'ka 1) sme overovali pomocou Studentovho t-testu, ktorý umožňuje porovnávat' priemery dvoch skupín.

Tab. 1 Rozdiely medzi chlapcami a dievčatami v skóre dotazníka

\begin{tabular}{|c|c|c|c|c|c|c|}
\hline Premenná & Pohlavie & $\mathbf{A M}$ & SD & $\mathbf{t}$ & df & Sig. \\
\hline \multirow{2}{*}{ Ú } & $\mathrm{CH}(\mathrm{N}=147)$ & 12.67 & 2.615 & \multirow{2}{*}{-1.442} & \multirow{2}{*}{322} & \multirow{2}{*}{0.150} \\
\hline & $\mathrm{D}(\mathrm{N}=177)$ & 12.24 & 2.786 & & & \\
\hline \multirow{2}{*}{$\mathbf{P}$} & $\mathrm{CH}(\mathrm{N}=147)$ & 13.61 & 3.215 & \multirow{2}{*}{-.716} & \multirow{2}{*}{322} & \multirow{2}{*}{0.475} \\
\hline & $\mathrm{D}(\mathrm{N}=177)$ & 13.36 & 3.204 & & & \\
\hline \multirow{2}{*}{$\mathbf{A}$} & $\mathrm{CH}(\mathrm{N}=147)$ & 18.88 & 3.592 & \multirow{2}{*}{-1.661} & \multirow{2}{*}{322} & \multirow{2}{*}{0.098} \\
\hline & $\mathrm{D}(\mathrm{N}=177)$ & 18.18 & 3.892 & & & \\
\hline \multirow{2}{*}{$\mathbf{O}$} & $\mathrm{CH}(\mathrm{N}=147)$ & 14.92 & 3.467 & \multirow{2}{*}{3.932} & \multirow{2}{*}{322} & \multirow{2}{*}{0.000} \\
\hline & $\mathrm{D}(\mathrm{N}=177)$ & 16.45 & 3.518 & & & \\
\hline \multirow{2}{*}{$\mathbf{S}$} & $\mathrm{CH}(\mathrm{N}=147)$ & 16.42 & 3.837 & \multirow{2}{*}{1.042} & \multirow{2}{*}{322} & \multirow{2}{*}{0.298} \\
\hline & $\mathrm{D}(\mathrm{N}=177)$ & 16.90 & 4.388 & & & \\
\hline \multirow{2}{*}{ Spolu } & $\mathrm{CH}(\mathrm{N}=147)$ & 76.50 & 12.322 & \multirow{2}{*}{0.452} & \multirow{2}{*}{322} & \multirow{2}{*}{0.652} \\
\hline & $\mathrm{D}(\mathrm{N}=177)$ & 77.13 & 12.515 & & & \\
\hline
\end{tabular}

Vysvetlivky:

AM - aritmetický priemer, SD - štandardná odchýlka, $t$ - testovacie kritérium, df - stupne vol’nosti, sig. - dosiahnutá signifikancia $>0,05$ nesignifikantná; $\leq 0,05$ signifikantná $* ; \leq 0,01$ vysoko signifikantná $* * ; \leq$ 0,001 vel'mi vysoko signifikantná***), $C H$ - chlapci, $D$-dievčatá, Ú - úlohy, $P$ - prístupnost', $A$ - angažovanie, $O$-obohatenie, $S$ - sebahodnotenie

Štatisticky významné výsledky sú zvýraznené. 
Tabul'ka nám poskytuje údaje získané štatistickým výpočtom Studentovho ttestu pre dve nezávislé premenné. Na základe výsledkov t-testu môžeme konštatovat', že sa potvrdilo diferencovanie medzi chlapcami a dievčatami a zaznamenali sme medzi nimi štatisticky významné rozdiely len $v$ jednej položke.

Medzi chlapcami a dievčatami je štatisticky významný rozdiel v odpovediach na otázky týkajúce sa dimenzie Obohatenie. Priemerné skóre u dievčat bolo významne vyššie $-\mathrm{AM}=16,45(\mathrm{SD}=3,518)$ ako u chlapcov $\mathrm{AM}=14,92$ $(\mathrm{SD}=3,467)$. V ostatných dimenziách sa chlapci a dievčatá štatisticky významne nelíšili.

Uvedená položka Obohatenie je na hladine významnosti $0,000(\leq 0,001)$, čo značí, že ide o vel'mi vysoko signifikantnú premennú. $Z$ uvedeného dôvodu môžeme hovorit’ o vysokej miere štatistickej významnosti.

$\mathrm{Z}$ uvedených výsledkov vyplýva, že u respondentov ženského pohlavia podiel'ajúcich sa na výskume sa prejavila častejšia miera Obohatenia zo sledovaných dimenzií oproti respondentom mužského pohlavia. Je nutné skonštatovat', že kritérium pohlavia v skóre dotazníka sa potvrdilo len $\mathrm{v}$ prípade tejto jednej položky.

\section{B) Kritérium ROČNÍK v skóre dotazníka}

Rozdiely medzi žiakmi podl'a ročníka (vid'. tabul'ka 2) sme overovali pomocou testu ANOVA, ktorý umožňuje porovnávat' priemery troch a viacerých skupín.

Tab. 2 Rozdiely medzi jednotlivými ročníkmi v skóre dotazníka

\begin{tabular}{|c|c|c|c|c|c|}
\hline Premenná & Ročník & $\mathbf{A M}$ & SD & $\mathbf{F}$ & sig. \\
\hline \multirow{3}{*}{ Ú } & $7(\mathrm{~N}=112)$ & 12.42 & 2.415 & \multirow{3}{*}{0.763} & \multirow{3}{*}{0.467} \\
\hline & $8(\mathrm{~N}=112)$ & 12.66 & 3.129 & & \\
\hline & $9(\mathrm{~N}=100)$ & 12.20 & 2.531 & & \\
\hline \multirow{3}{*}{$\mathbf{P}$} & $7(\mathrm{~N}=112)$ & 13.65 & 2.805 & \multirow{3}{*}{15.941} & \multirow{3}{*}{0.000} \\
\hline & $8(\mathrm{~N}=112)$ & 14.49 & 3.191 & & \\
\hline & $9(\mathrm{~N}=100)$ & 12.13 & 3.206 & & \\
\hline \multirow{3}{*}{$\mathbf{A}$} & $7(\mathrm{~N}=112)$ & 18.20 & 3.609 & \multirow{3}{*}{10.314} & \multirow{3}{*}{0.000} \\
\hline & $8(\mathrm{~N}=112)$ & 19.71 & 3.857 & & \\
\hline & $9(\mathrm{~N}=100)$ & 17.48 & 3.503 & & \\
\hline \multirow{3}{*}{$\mathbf{O}$} & $7(\mathrm{~N}=112)$ & 16.56 & 3.934 & \multirow{3}{*}{16.703} & \multirow{3}{*}{0.000} \\
\hline & $8(\mathrm{~N}=112)$ & 16.41 & 3.245 & & \\
\hline & $9(\mathrm{~N}=100)$ & 14.12 & 2.924 & & \\
\hline \multirow{3}{*}{$\mathbf{S}$} & $7(\mathrm{~N}=112)$ & 16.81 & 3.719 & \multirow{3}{*}{17.802} & \multirow{3}{*}{0.000} \\
\hline & $8(\mathrm{~N}=112)$ & 18.14 & 4.102 & & \\
\hline & $9(\mathrm{~N}=100)$ & 14.91 & 4.020 & & \\
\hline \multirow{3}{*}{ Spolu } & $7(\mathrm{~N}=112)$ & 77.64 & 11.713 & \multirow{3}{*}{22.054} & \multirow{3}{*}{0.000} \\
\hline & $8(\mathrm{~N}=112)$ & 81.41 & 11.967 & & \\
\hline & $9(\mathrm{~N}=100)$ & 70.84 & 11.293 & & \\
\hline
\end{tabular}

Vysvetlivky: 
AM - aritmetický priemer, SD - štandardná odchýlka, F - testovacie kritérium, sig. - dosiahnutá signifikancia ( $>0,05$ nesignifikantná; $\leq$ 0,05 signifikantná *; $\leq 0,01$ vysoko signifikantná **; $\leq 0,001$ vel'mi vysoko signifikantná***), $U$ - úlohy, $P$ - prístupnost', $A$ - angažovanie, $O$ obohatenie, $S$ - sebahodnotenie

Štatisticky významné výsledky sú zvýraznené.

Vyššie uvedené tabul'kové znázornenie rozdielov medzi jednotlivými ročníkmi v skóre dotazníka ponúka údaje získané štatistickým výpočtom testu ANOVA porovnávajúceho tri a viac nezávislých premenných. $\mathrm{V}$ danej tabul'ke sú pri jednotlivých položkách uvedené ročníky, aritmetické priemery, smerodajné odchýlky a vždy pri ich troch hodnotách porovnania troch súborov je uvedená hodnota vypočítaného t-testu a štatistická významnost'. Z dôvodu popisu výsledkov výskumu boli pre nás zaujímavé predovšetkým štatisticky signifikantné údaje o pravdepodobnosti chyby $\mathrm{p}<0,05$. Štatisticky významné výsledky sú v tabul'ke zvýraznené.

Na základe výsledkov tohto testu môžeme skonštatovat', že sa potvrdilo diferencovanie medzi 7., 8. a 9. ročníkmi, pričom sme zaznamenali medzi nimi štatisticky významný rozdiel vodpovediach na otázky týkajúce sa všetkých dimenzií ( $\mathrm{P}$ - prístupnost', A - angažovanie, $\mathrm{O}$ - obohatenie, $\mathrm{S}$ sebahodnotenie) okrem prvej dimenzii (Ú - úlohy), aj v celkovom skóre.

Z tabul'ky vyplýva, že štatisticky významné výsledky v jednotlivých ročníkoch sa objavujú v štyroch položkách z piatich, teda okrem prvej, pri ktorej nemožno hovorit' o signifikantných výsledkoch.

Najvyššiu mieru spol'ahlivosti pri jednotlivých dimenziách, ktoré sa vyskytujú vo všetkých ročníkoch (7., 8., 9. ročníkoch), dosahujú výsledky položiek P - prístupnost', A - angažovanie, $\mathrm{O}$ - obohatenie, $\mathrm{S}$ sebahodnotenie, všetky na rovnakej hladine významnosti $0,000(\leq 0,001, \mathrm{t}$.j. vel'mi vysoko signifikantná***). Preto môžeme hovorit' vo všetkých prípadoch o vel'mi vysokej miere štatistickej významnosti. To platí aj pre spoločné celkové skóre.

Medzi jednotlivými ročníkmi je štatisticky významný rozdiel v odpovediach na otázky týkajúce sa spomínaných dimenzií. Ak by sme sa zamerali najskôr na vyhodnotenie jednotlivých ročníkov podl'a najvyššieho dosiahnutého aritmetického priemeru, tak v 8. ročníku bolo najvyššie dosiahnuté priemerné skóre $\mathrm{AM}=19,71$ ( $\mathrm{SD}=3,857)$, potom v 9. ročníku bol významne vyšší priemer $-\mathrm{AM}=17,48(\mathrm{SD}=3,503)$ ako v 7. ročníku o niečo nižší $-\mathrm{AM}=$ $16,81(\mathrm{SD}=3,719)$.

Vo všetkých štatisticky významných dimenziách sme identifikovali v 9. ročníku najnižšie hodnoty priemeru, pričom pre dimenziu $\mathrm{P}$ - prístupnost' $\mathrm{AM}=12,13(\mathrm{SD}=3,206), \mathrm{A}-$ angažovanie $-\mathrm{AM}=17,48(\mathrm{SD}=3,503), \mathrm{O}-$ obohatenie $-\mathrm{AM}=14,12(\mathrm{SD}=2,924), \mathrm{S}-$ sebahodnotenie $-\mathrm{AM}=14,91$ $(\mathrm{SD}=4,020)$.

Z hl'adiska jednotlivých položiek sa na prvom mieste s najvyššie dosiahnutým priemerným skóre umiestnila položka $\mathrm{A}$ - angažovanie $-\mathrm{AM}=$ $19,71(\mathrm{SD}=3,857)$, potom nasledovala položka $\mathrm{S}-$ sebahodnotenie $-\mathrm{AM}=$ $16,81(\mathrm{SD}=3,719)$, predposledná pozícia patrila položke $\mathrm{O}$ - obohatenie - 
$\mathrm{AM}=16,56(\mathrm{SD}=3,934)$ a nakoniec $\mathrm{P}-$ prístupnost' $^{-} \mathrm{AM}=14,49(\mathrm{SD}=$ $3,191)$.

$\mathrm{Z}$ dosiahnutého celkového skóre vyplýva, že vedúce postavenie $\mathrm{z}$ ročníkov zastupuje 8. ročník s najvyššie dosiahnutým priemerným skóre - $\mathrm{AM}=81,41$ $(\mathrm{SD}=11,967)$, strednú pozíciu zastáva 7 . ročník s priemerom $-\mathrm{AM}=77,64$ $(\mathrm{SD}=11,713)$ a ako posledné umiestnenie má 9. ročník s najnižším priemerným skóre $-\mathrm{AM}=70,84$ ( $\mathrm{SD}=11,293)$.

$\mathrm{Na}$ základe uvedených výsledkov môžeme konštatovat', že medzi jednotlivými ročníkmi je štatisticky významný rozdiel v odpovediach na otázky týkajúce sa všetkých dimenzií okrem prvej - Úlohy, pričom najnižšie hodnoty priemeru sme vo všetkých dimenziách identifikovali v 9. ročníku.

\section{C) Kritérium ROČNÍK v skóre pozorovania}

Rozdiely v pozorovaní jednotlivých ročníkov (pozri tabul'ku 3) sme overovali pomocou testu ANOVA, ktorý umožňuje porovnávat' priemery troch a viacerých skupín.

Tab. 3 Rozdiely medzi jednotlivými ročníkmi v pozorovaní

\begin{tabular}{|c|c|c|c|c|c|}
\hline Premenná & Ročník & $\mathbf{A M}$ & SD & $\mathbf{F}$ & sig. \\
\hline \multirow{3}{*}{$\mathbf{P}$} & $7(\mathrm{~N}=138)$ & 3.46 & 0.706 & \multirow{3}{*}{1.069} & \multirow{3}{*}{0.344} \\
\hline & $8(\mathrm{~N}=145)$ & 3.50 & 0.636 & & \\
\hline & $9(\mathrm{~N}=145)$ & 3.59 & 0.838 & & \\
\hline \multirow{3}{*}{$\mathbf{A}$} & $7(\mathrm{~N}=138)$ & 3.77 & 0.676 & \multirow{3}{*}{0.514} & \multirow{3}{*}{0.599} \\
\hline & $8(\mathrm{~N}=145)$ & 3.80 & 0.830 & & \\
\hline & $9(\mathrm{~N}=145)$ & 3.71 & 0.772 & & \\
\hline \multirow{3}{*}{ O } & $7(\mathrm{~N}=138)$ & 2.96 & 1.192 & \multirow{3}{*}{14.541} & \multirow{3}{*}{0.000} \\
\hline & $8(\mathrm{~N}=145)$ & 2.84 & 1.072 & & \\
\hline & $9(\mathrm{~N}=145)$ & 2.28 & 1.187 & & \\
\hline \multirow{3}{*}{$\mathbf{S}$} & $7(\mathrm{~N}=138)$ & 2.47 & 1.128 & \multirow{3}{*}{4.396} & \multirow{3}{*}{0.013} \\
\hline & $8(\mathrm{~N}=145)$ & 2.08 & 1.231 & & \\
\hline & $9(\mathrm{~N}=145)$ & 2.10 & 1.363 & & \\
\hline \multirow{3}{*}{ Ú } & $7(\mathrm{~N}=138)$ & 1.24 & 1.022 & \multirow{3}{*}{9.690} & \multirow{3}{*}{0.000} \\
\hline & $8(\mathrm{~N}=145)$ & 0.74 & 0.771 & & \\
\hline & $9(\mathrm{~N}=145)$ & 0.96 & 1.027 & & \\
\hline \multirow{3}{*}{ Spolu } & $7(\mathrm{~N}=138)$ & 13.91 & 2.744 & \multirow{3}{*}{6.641} & \multirow{3}{*}{0.001} \\
\hline & $8(\mathrm{~N}=145)$ & 12.96 & 3.020 & & \\
\hline & $9(\mathrm{~N}=145)$ & 12.63 & 3.312 & & \\
\hline
\end{tabular}

Vysvetlivky:

AM - aritmetický priemer, SD - štandardná odchýlka, F - testovacie kritérium, sig. - dosiahnutá signifikancia (>0,05 nesignifikantná; $\leq 0,05$ signifikantná $* ; \quad \leq 0,01$ vysoko signifikantná $* * ; \quad \leq 0,001$ velmi vysoko signifikantná***) $U$ - úlohy, $P$ - prístupnost', $A$ - angažovanie, $O$ obohatenie, $S$ - sebahodnotenie

Štatisticky významné výsledky sú zvýraznené.

Vysokú mieru spol'ahlivosti pri jednotlivých inkluzívnych dimenziách pozorovania, ktoré sa vyskytujú významne častejšie $\mathrm{v}$ siedmych ako v ôsmych či deviatych ročníkoch, sa objavujú v troch už spomínaných 
položkách. Jednou z nich je $\mathrm{O}$ - obohatenie na hladine $0,000(\leq 0,001$ vel'mi vysoko signifikantná***) s priemerným skóre - AM = 2,96 ( $\mathrm{SD}=1,192)$. Môžeme teda hovorit' o vel'mi vysokej miere štatistickej významnosti. Štatisticky vysoko signifikantný výsledok dosiahla aj položka S sebahodnotenie na hladine 0,013 so skóre $-\mathrm{AM}=2,47 \quad(\mathrm{SD}=1,128)$. Položka Ú - úlohy dosiahla štatisticky vel'mi vysoko signifikantné výsledky na hladine významnosti 0,000 s priemerným skóre $\mathrm{AM}=1,24(\mathrm{SD}=1,022)$. Jediná dimenzia, ktorá sa objavuje s najvyšším priemerným skóre vo všetkých ročníkoch, je $\mathrm{O}$ - obohatenie, kde v 7. ročníku menovaná položka, ako aj v ostatných ročníkoch, dosiahla štatisticky vel'mi vysoko signifikantný výsledok $-\mathrm{s} A M=2,96(\mathrm{SD}=1,192)$, v 8. ročníku už o niečo menší priemer $-\mathrm{AM}=2,84(\mathrm{SD}=1,072)$ a pre 9. ročník je typické priemerné skóre $-\mathrm{AM}=$ $2,28(\mathrm{SD}=1,187)$.

V jedinej, štatisticky významnej dimenzii Ú - úlohy, na hladine 0,000 s vel'mi vysokou signifikanciou, sme identifikovali vo všetkých 7., 8. a 9. ročníkoch najnižšie hodnoty priemeru (najmenej frekvencií), pričom pre 7 . ročník je najnižšie priemerné skóre - $\mathrm{AM}=1,24(\mathrm{SD}=1,022), 8$. ročník $\mathrm{AM}=0,74(\mathrm{SD}=0,771)$ a pre 9. ročník je najmenší priemer $-\mathrm{AM}=0,96$ $(\mathrm{SD}=1,027)$.

Zo záverečného celkového skóre vyplýva, že vedúce postavenie z ročníkov zastupuje v postupnosti najskôr 7. ročník s najvyššie dosiahnutým priemerným skóre $-\mathrm{AM}=13,91(\mathrm{SD}=13,91)$, potom nasleduje 8. ročník s priemerom $-\mathrm{AM}=12,96(\mathrm{SD}=3,020)$ a ako posledné umiestnenie má 9. ročník s najnižším priemerným skóre - $\mathrm{AM}=12,63(\mathrm{SD}=3,312)$. Uvádzali sme štatisticky vel'mi vysoko signifikantné výsledky na hladine významnosti 0,001 .

Na záver môžeme skonštatovat', že medzi jednotlivými ročníkmi sme identifikovali štatisticky významné rozdiely vpozorovaní iba v troch dimenziách $\mathrm{O}$ - obohatenie, $\mathrm{S}$ - sebahodnotenie a Ú - úlohy, aj v celkovom skóre.

\section{D) Kritérium VEK v skóre pozorovania}

Pre overenie vzt'ahu medzi vekom učitel'a a hodnotami skóre jednotlivých dimenzií sme použili Pearsonov korelačný koeficient $\mathrm{r}(\mathrm{N}=428)$.

Tab. 4 Hodnoty korelačných koeficientov pre vek učitel’a a jednotlivé dimenzie

\begin{tabular}{|c|c|c|c|c|c|c|c|}
\hline & Vek & $\mathbf{P}$ & $\mathbf{A}$ & O & $\mathbf{S}$ & Ú & Spolu \\
\hline Vek & 1 & 0.061 & -0.058 & 0.055 & -0.040 & $\stackrel{-}{0.197 * *}$ & -0.057 \\
\hline $\mathbf{P}$ & 0.061 & 1 & $0.273 * *$ & $0.099 *$ & $0.301 * *$ & $0.123^{*}$ & $0.505 * *$ \\
\hline $\mathbf{A}$ & -0.058 & $0.273 * *$ & 1 & $0.233 * *$ & $0.364 * *$ & $0.135^{-} * *$ & $0.509 * *$ \\
\hline O & 0.055 & $0.099 *$ & $0.233 * *$ & 1 & $0.591 * *$ & $0.104^{*}$ & $0.740 * *$ \\
\hline $\mathbf{S}$ & -0.040 & $0.301 * *$ & $0.364 * *$ & $0.591 * *$ & 1 & $0.132 * *$ & $0.839 * *$ \\
\hline Ú & - & $0.123^{*}$ & - & $0.104 *$ & $0.132 * *$ & 1 & $0.403 * *$ \\
\hline
\end{tabular}




\begin{tabular}{|l|c|c|c|c|c|c|c|}
\hline & $\mathbf{0 . 1 9 7 * *}$ & & $0.135 * *$ & & & \\
\hline Spolu & -0.057 & $0.505 * *$ & $0.509 * *$ & $0.740 * *$ & $0.839 * *$ & $0.403 * *$ & 1 \\
\hline
\end{tabular}

\section{Vysvetlivky:}

$P$ - pristupnost', $A$ - angažovanie, $O$ - obohatenie, $S$ - sebahodnotenie, $U$ úlohy

* Korelácia je signifikantná na úrovni $\leq 0,05$

** Korelácia je signifikantná na úrovni $\leq 0,01$

*** Korelácia je signifikantná na úrovni $\leq 0,001$

Štatisticky významné výsledky sú zvýraznené.

Zaujímalo nás, či je možná existencia vzt’ahu medzi vekom učitel’a a hodnotami skóre jednotlivých dimenzií $\mathrm{P}$ - prístupnost', A angažovanie, $\mathrm{O}$ - obohatenie, $\mathrm{S}$ - sebahodnotenie, Ú - úlohy.

$\mathrm{Na}$ základe získaných údajov konštatujeme, že sme z vyššie uvedenej tabul'ky 4 zaznamenali štatisticky významný výsledok medzi dvoma premennými na hladine $-0,197$ s koreláciou, ktorá je vysoko signifikantná na úrovni $\leq 0,01$. Identifikovali sme, že existuje jediný, štatisticky významný vzt’ah medzi vekom učitel'a a hodnotou skóre v dimenzii Ú - úlohy.

Táto súčinová korelácia nadobudla zápornú hodnotu a blíži sa $\mathrm{k}$ hodnote -1 , čo znamená že medzi porovnávanými premennými, $\mathrm{v}$ našom prípade vekom učitel'a a hodnotou skóre v dimenzii Ú - úlohy je tesnejší vzt'ah. Záporný korelačný koeficient vyjadruje, že medzi premennými, ktoré porovnávame, je opačný vzt’ah, t.j. vysokým hodnotám jednej premennej sú zodpovedajúce skôr nižšie hodnoty druhej premennej a naopak.

Zistené hodnoty korelačných koeficientov pre vek učitel'a a ostatné štyri dimenzie $\mathrm{P}$ - prístupnost', A - angažovanie, $\mathrm{O}$ - obohatenie, S sebahodnotenie nepovažujeme za štatisticky významné výsledky.

E) Kritérium ROKY PRAXE v skóre pozorovania

Pre overenie vzt’ahu medzi rokmi praxe učitel'a a hodnotami skóre jednotlivých dimenzií sme použili Pearsonov korelačný koeficient $\mathrm{r}(\mathrm{N}=428)$. Namerané výsledky znázorňuje nižšie tabul'ka 5.

Tab. 5 Hodnoty korelačných koeficientov pre roky praxe učitel’a a jednotlivé dimenzie

\begin{tabular}{|c|c|c|c|c|c|c|c|}
\hline & Prax & $\mathbf{P}$ & $\mathbf{A}$ & $\mathbf{O}$ & $\mathbf{S}$ & Ú & Spolu \\
\hline Prax & 1 & $0.120 *$ & -0.006 & $0.103 *$ & 0.014 & $\stackrel{-}{0.224 * *}$ & 0.002 \\
\hline $\mathbf{P}$ & $0.120 *$ & 1 & $0.273 * *$ & $0.099^{*}$ & $0.301 * *$ & $0.123^{*}$ & $0.505^{* *}$ \\
\hline $\mathbf{A}$ & -0.006 & $0.273 * *$ & 1 & $0.233 * *$ & $0.364 * *$ & $\begin{array}{c}- \\
0.135^{* *}\end{array}$ & $0.509 * *$ \\
\hline O & $0.103^{*}$ & $0.099^{*}$ & $0.233^{* *}$ & 1 & $0.591 * *$ & $0.104 *$ & $0.740 * *$ \\
\hline $\mathbf{S}$ & 0.014 & $0.301 * *$ & $0.364 * *$ & $0.591 * *$ & 1 & $0.132 * *$ & $0.839 * *$ \\
\hline
\end{tabular}




\begin{tabular}{|c|c|c|c|c|c|c|c|}
\hline Ú & $-\overline{0.24}^{* *}$ & $0.123 *$ & $-\overline{-}^{* *}$ & $0.104 *$ & $0.132 * *$ & 1 & $0.403 * *$ \\
\hline Spolu & 0.002 & $0.505 * *$ & $0.509 * *$ & $0.740 * *$ & $0.839 * *$ & $0.403 * *$ & 1 \\
\hline
\end{tabular}

\section{Vysvetlivky:}

$P$ - prístupnost', $A$ - angažovanie, $O$ - obohatenie, $S$ - sebahodnotenie, $U$ úlohy

* Korelácia je signifikantná na úrovni $\leq 0,05$

** Korelácia je signifikantná na úrovni $\leq 0,01$

*** Korelácia je signifikantná na úrovni $\leq 0,001$. Štatisticky významné výsledky sú zvýraznené.

V d'alšom overovaní vzt'ahov sme chceli zistit', či existuje vztah medzi rokmi praxe a hodnotami skóre jednotlivých dimenzií, a to $\mathrm{P}$ - prístupnost', A angažovanie, $\mathrm{O}$ - obohatenie, $\mathrm{S}$ - sebahodnotenie, Ú - úlohy.

Pomocou Pearsonovho korelačného koeficientu sme identifikovali štatisticky významný vzt’ah medzi rokmi praxe učitel'a a dimenziami $\mathrm{P}$ - prístupnost', $\mathrm{O}$ - obohatenie a Ú - úlohy.

Prostredníctvom získaných údajov môžeme konštatovat', že sme zaznamenali štatisticky významné výsledky medzi dvoma premennými v troch hladinách, a to na hladine $0,120 \mathrm{~s}$ koreláciou signifikantnou na úrovni $\leq 0,05$. Tým sme potvrdili, že existuje štatisticky významný vztah medzi rokmi praxe učitela a hodnotou skóre $\mathrm{v}$ dimenzii $\mathrm{P}$ - prístupnost'.

Druhá hladina korelácie signifikantná tiež na úrovni $\leq 0,05$ bola 0,103 znamená potvrdenie štatisticky významného vztahu medzi rokmi praxe učitel'a a rovnako tak hodnotou skóre v dimenzii $\mathrm{O}$ - obohatenie.

Tieto dva uvedené Pearsonove korelačné koeficienty nadobudli kladnú hodnotu, vypovedajúce tak o závislosti premenných. Čím viac sa vypočítaná hodnota koeficientov korelácie blíži $\mathrm{k}$ hodnote +1 , tým tesnejší je vzt’ah medzi porovnávanými premennými.

Ako posledná, štatisticky významná nám vyšla tretia hladina korelácie vysoko signifikantná na úrovni $\leq 0,01$ s číselným vyjadrením $-0,224$ ako potvrdenie štatisticky významného vzt’ahu medzi rokmi praxe učitel'a a hodnotou skóre v dimenzii Ú - úlohy. Súčinová korelácia nadobudla zápornú hodnotu a blíži sa $\mathrm{k}$ hodnote -1 , čo vyjadruje, že medzi porovnávanými premennými, $\mathrm{v}$ našom prípade rokmi praxe učitel'a a hodnotou skóre $\mathrm{v}$ dimenzii Ú - úlohy je tesnejší vzt’ah. Záporný korelačný koeficient znamená, že medzi porovnávanými premennými je opačný vzt’ah, t.j. vysokým hodnotám jednej premennej sú zodpovedajúce skôr nižšie hodnoty druhej premennej a naopak.

Zvyšné hodnoty korelačných koeficientov pre roky praxe učitel'a a dimenzie A - angažovanie, S - sebahodnotenie nepokladáme za štatisticky významné výsledky.

\section{F) Kritérium POČET ŽIAKOV V TRIEDE v skóre pozorovania}

Pre overenie vztahu medzi počtom žiakov $\mathrm{v}$ triede a hodnotami skóre jednotlivých dimenzií sme použili Pearsonov korelačný koeficient $\mathrm{r}(\mathrm{N}=428)$, ktorého výsledky v tabul'kovom stvárnení znázorňujeme nižšie. 
Tab. 6 Hodnoty korelačných koeficientov pre počet žiakov v triede a jednotlivé dimenzie

\begin{tabular}{|c|c|c|c|c|c|c|c|}
\hline & Žiaci & $\mathbf{P}$ & $\mathbf{A}$ & $\mathbf{O}$ & $\mathbf{S}$ & Ú & Spolu \\
\hline Žiaci & 1 & -0.012 & $\stackrel{-}{0.127 * *}$ & 0.016 & $\overline{-}^{-}{ }^{229} * *$ & 0.082 & $-0.096 *$ \\
\hline $\mathbf{P}$ & -0.012 & 1 & $0.273^{* *}$ & $0.099 *$ & $0.301 * *$ & $0.123^{*}$ & $0.505 * *$ \\
\hline $\mathbf{A}$ & $\stackrel{-}{0.127 * *}$ & $0.273^{* *}$ & 1 & $0.233^{* *}$ & $0.364 * *$ & $\stackrel{-}{0.135^{* *}}$ & $0.509 * *$ \\
\hline O & 0.016 & $0.099 *$ & $0.233^{* *}$ & 1 & $0.591 * *$ & $0.104 *$ & $0.740 * *$ \\
\hline $\mathbf{S}$ & $0.229 * *$ & $0.301 * *$ & $0.364 * *$ & $0.591 * *$ & 1 & $0.132 * *$ & $0.839 * *$ \\
\hline Ú & 0.082 & $0.123^{*}$ & $\stackrel{-}{0.135^{* *}}$ & $0.104^{*}$ & $0.132 * *$ & 1 & $0.403 * *$ \\
\hline Spolu & $-0.096 *$ & $0.505^{* *}$ & $0.509 * *$ & $0.740 * *$ & $0.839 * *$ & $0.403 * *$ & 1 \\
\hline
\end{tabular}

Vysvetlivky:

$P$ - pristupnost', $A$ - angažovanie, $O$ - obohatenie, $S$ - sebahodnotenie, $U$ úlohy

* Korelácia je signifikantná na úrovni $\leq 0,05$

** Korelácia je signifikantná na úrovni $\leq 0,01$

*** Korelácia je signifikantná na úrovni $\leq 0,001$.

Štatisticky významné výsledky sú zvýraznené.

V posledných výpočtoch hodnôt korelačných koeficientov pre počet žiakov $\mathrm{v}$ triede a dimenzie $\mathrm{P}$ - prístupnost', $\mathrm{A}$ - angažovanie, $\mathrm{O}$ - obohatenie, $\mathrm{S}$ sebahodnotenie, Ú - úlohy bolo naším zámerom zistit' prítomnost' vzt'ahu medzi uvedenými premennými.

Prostredníctvom štatistickej metódy pre analýzu metrických údajov sa nám podarilo zidentifikovat' štatisticky významný vzt’ah medzi počtom žiakov v triede a dvomi dimenziami A - angažovanie i S - sebahodnotenie. Štatistická významnost' sa potvrdila aj v celkovom skóre.

Vyhodnotením získaných údajov konštatujeme, že sme zaznamenali štatisticky významné výsledky medzi dvoma premennými celkovo $\mathrm{v}$ troch hladinách. Na hladine $-0,127$ s koreláciou vysoko signifikantnou na úrovni $\leq$ 0,01 sa nám potvrdil štatisticky významný vzt’ah medzi počtom žiakov $\mathrm{v}$ triede a hodnotou skóre v dimenzii A - angažovanie.

Ďalšia hladina korelácie je rovnako vysoko signifikantná na úrovni $\leq 0,01$ s hodnotou $-0,229$, čo značí potvrdenie štatisticky významného vzt’ahu medzi premennými počet žiakov $\mathrm{v}$ triede a hodnota skóre $\mathrm{v}$ dimenzii $\mathrm{S}$ sebahodnotenie.

Záverečná, štatisticky významná hladina korelácie signifikantná na úrovni $\leq$ 0,05 s číselným vyjadrením -0,096 potvrdzuje štatisticky významný vzt’ah medzi počtom žiakov v triede a hodnotou celkového skóre.

Všetky vymenované korelácie nadobudli zápornú hodnotu a blížia sa $\mathrm{k}$ hodnote -1 , najväčšmi celkové skóre, čo značí, že medzi porovnávanými premennými, a to počtom žiakov $\mathrm{v}$ triede a hodnotou skóre $\mathrm{v}$ dimenziách $\mathrm{A}$ angažovanie, $\mathrm{S}$ - sebahodnotenie a v celkovom skóre je tesnejší vzt’ah. 
Záporný korelačný koeficient vyjadruje, že medzi porovnávanými premennými je opačný vzt’ah, t.j. vysokým hodnotám jednej premennej sú zodpovedajúce skôr nižšie hodnoty druhej premennej a opačne.

Zostávajúce hodnoty korelačných koeficientov pre počet žiakov v triede a dimenzie $\mathrm{P}$ - prístupnost', $\mathrm{O}$ - obohatenie a Ú - úlohy nepovažujeme za štatisticky významné výsledky.

V závere môžeme konštatovat', že sme identifikovali štatisticky významný vzt’ah medzi počtom žiakov $\mathrm{v}$ triede a dimenziami $\mathrm{A}$ - angažovanie, $\mathrm{S}$ sebahodnotenie, ale aj v celkovom skóre.

Ciel’om výskumného šetrenia bolo približit' procesuálnu stránku prístupu rešpektujúceho diverzitu školskej triedy a dokázat' vzájomný vzt’ah medzi mierou dodržiavania princípov inklúzie vo výchovno-vzdelávacom procese a úrovňou hodnotenia podmienok inkluzívneho vzdelávania vzhl’adom na špeciálne výchovno-vzdelávacie potreby žiakov v rámci škôl bežného typu na 2. stupni základných škôl poskytujúcich nižšie sekundárne vzdelávanie v Bratislavskom a Nitrianskom kraji.

Našim výskumným šetrením sme zmapovali dodržiavanie princípov inklúzie učitel'mi vo výchovno-vzdelávacom procese a zistili sme reálny stav uplatňovania inkluzívnych prístupov vo vyučovaní ako so žiakmi intaktnými, tak aj so špeciálnymi výchovno-vzdelávacími potrebami.

Stanovili sme si nasledovnú hypotézu, ktorej platnost' sme overovali výskumom:

- H 1 Predpokladali sme, že existuje priamo úmerná závislost' medzi dodržiavaním princípov inklúzie a úrovňou kvality inklúzie žiakov so špeciálnymi výchovno-vzdelávacími potrebami, to znamená, že čím viac sa budú uplatňovat' princípy inklúzie, tým bude vyššia spokojnost' žiakov so špeciálnymi výchovno-vzdelávacími potrebami so životom $\mathrm{v}$ triede a naopak.

Vzt’ah medzi stúpajúcou mierou dodržiavania princípov inklúzie učitel’mi a úrovňou kvality podmienok inklúzie žiakov $\mathrm{v}$ triede sme overovali pomocou výpočtových programov MS Excel 2007 a štatistického softvéru SPSS 8.0 for Windows prostredníctvom Studentovho t-testu, testu ANOVA a Pearsonovho koeficientu korelácie. Dospeli sme k nasledovnému:

- H 1.1 Predpokladali sme, že vek učitel'a nedeterminuje oblast' rešpektovania princípov inklúzie $\mathrm{v}$ pedagogickej praxi.

$\mathrm{Na}$ overenie vzt'ahu medzi vekom učitel'a a hodnotami skóre jednotlivých dimenzií sme použili Pearsonov korelačný koeficient $r$ $(\mathrm{N}=428)$. Na základe získaných údajov konštatujeme, že sme zaznamenali štatisticky významný výsledok medzi dvoma premennými na hladine $-0,197$ s koreláciou, ktorá je vysoko signifikantná na úrovni $\leq 0,01$. Pri overovaní vzt’ahu medzi vekom učitel'a a hodnotami skóre jednotlivých dimenzií sme identifikovali, že existuje jediný, štatisticky významný vzt’ah medzi vekom učitel'a a hodnotou skóre v dimenzii Ú - úlohy. Vzhl'adom na skutočnost', že $\mathrm{v}$ tomto prípade vyšiel záporný korelačný koeficient, ktorý vyjadruje, že medzi porovnávanými premennými je opačný vzt’ah, t.j. vysokým hodnotám jednej premennej sú zodpovedajúce skôr nižšie hodnoty druhej premennej a naopak, môžeme konštatovat', že 
čím majú učitelia nižší počet rokov, tým zadávajú častejšie domáce úlohy prispievajúce $\mathrm{k}$ učeniu všetkých žiakov, ako učitelia $\mathrm{s}$ pribúdajúcim vyšším vekom. Výskumným overovaním sme zistili, že hypotéza H 1.1 sa potvrdila.

- H 1.2 Predpokladali sme, že existuje vzt’ah medzi dížkou pedagogickej praxe učitel'ov a dodržiavaním podmienok inklúzie vo výchovno-vzdelávacom procese.

Pri overovaní vzt'ahu medzi rokmi praxe učitel'a a hodnotami skóre jednotlivých dimenzií sme použili Pearsonov korelačný koeficient $r$ $(\mathrm{N}=428)$, pomocou ktorého sme identifikovali štatisticky významný vzt'ah medzi rokmi praxe učitel'a a dimenziami $\mathrm{P}$ - prístupnost', $\mathrm{O}$ obohatenie a Ú - úlohy. Zo získaných údajov môžeme konštatovat', že sme zaznamenali štatisticky významné výsledky medzi dvoma premennými $\mathrm{v}$ troch hladinách, a to na hladine $0,120 \mathrm{~s}$ koreláciou signifikantnou na úrovni $\leq 0,05$. Potvrdilo sa, že existuje štatisticky významný vzt'ah medzi rokmi praxe učitel'a a hodnotou skóre v dimenzii $\mathrm{P}$ - prístupnost'. Ako druhá hladina korelácie signifikantná takisto na úrovni $\leq 0,05$ bola 0,103 , čo znamená potvrdenie štatisticky významného vzt’ahu medzi rokmi praxe učitel'a a rovnako tak hodnotou skóre v dimenzii $\mathrm{O}$ - obohatenie. V týchto prípadoch korelačné koeficienty nadobudli kladnú hodnotu, čo vyjadruje závislost' premenných v tom, že čím viac sa vypočítaná hodnota koeficientov korelácie blíži $\mathrm{k}$ hodnote +1 , tým tesnejší je vzt’ah medzi porovnávanými premennými, a to priamo úmerný. Z uvedeného vyplýva, že učitelia s pribúdajúcimi rokmi praxe frekventovanejšie uplatňujú vo svojej pedagogickej činnosti výchovno-vzdelávací proces prístupný všetkým žiakom, t.j. rešpektujúci ich jedinečnost' i rozmanitost' a odlišnosti medzi žiakmi využívajú ako zdroj, vzájomné obohatenie vyučovania a učenia. Posledná, štatisticky významná vyšla tretia, záporná hladina korelácie vysoko signifikantná na úrovni $\leq 0,01$ s číselným vyjadrením -0,224 ako potvrdenie štatisticky významného vzt’ahu medzi rokmi praxe učitel'a a hodnotou skóre v dimenzii Ú - úlohy. Súčinová korelácia sa blížila $\mathrm{k}$ hodnote -1 , čo vyjadruje, že medzi porovnávanými premennými je tesnejší vzt'ah a záporný korelačný koeficient značí medzi porovnávanými premennými opačný vzt'ah, tzn. vysokým hodnotám jednej premennej sú zodpovedajúce skôr nižšie hodnoty druhej premennej a opačne. Z uvedeného môžeme vyjadrit' záver, že čím majú učitelia menej rokov praxe, tým častejšie zadávajú domáce úlohy, ktoré prispievajú k učeniu všetkých žiakov, ako učitelia vykonávajúci pedagogickú prax viac rokov. Tieto zistenia potvrdila hypotéza H 1.2.

- H 1.3 Predpokladali sme, že existuje vzt'ah medzi dodržiavaním princípov inklúzie vo vyučovaní a jednotlivými pozorovanými ročníkmi.

Rozdiely v pozorovaní jednotlivých ročníkov sme overovali pomocou testu ANOVA, ktorý umožňuje porovnávat' priemery troch a viacerých skupín. $\mathrm{V}$ jednotlivých ročníkov v skóre 
pozorovania nám umožnili skonštatovat', že medzi jednotlivými ročníkmi sme identifikovali štatisticky významné rozdiely $\mathrm{v}$ pozorovaní, ale iba $\mathrm{v}$ troch dimenziách $\mathrm{O}$ - obohatenie, $\mathrm{S}$ sebahodnotenie a Ú - úlohy a aj v celkovom skóre. Vysoká miera spol'ahlivosti pri inkluzívnych dimenziách pozorovania, ktoré sa vyskytujú významne častejšie $v$ siedmych ako v ôsmych či deviatych ročníkoch, sa objavuje v troch položkách. Jednou je O obohatenie na hladine $0,000 \quad(\leq 0,001$ vel'mi vysoko signifikantná***) s priemerným skóre - AM = 2,96 (SD = 1,192). Môžeme hovorit' o vel'mi vysokej miere štatistickej významnosti. Štatisticky vysoko signifikantný výsledok dosiahla i položka S sebahodnotenie na hladine 0,013 so skóre $-\mathrm{AM}=2,47$ (SD = 1,128). Položka Ú - úlohy dosiahla štatisticky vel'mi vysoko signifikantné výsledky na hladine významnosti $0,000 \mathrm{~s}$ priemerným skóre $\mathrm{AM}=1,24(\mathrm{SD}=1,022)$. Jedna dimenzia, ktorá sa objavuje s najvyšším priemerným skóre vo všetkých ročníkoch, je O obohatenie, ktorá $\mathrm{v} 7$. ročníku, ako aj v ostatných ročníkoch, dosiahla štatisticky vel'mi vysoko signifikantný výsledok $-\mathrm{s}$ AM = $2,96(\mathrm{SD}=1,192), \mathrm{v} 8$. ročníku už o niečo menší priemer $-\mathrm{AM}=$ $2,84(\mathrm{SD}=1,072)$ a pre 9. ročník priemerné skóre $-\mathrm{AM}=2,28(\mathrm{SD}$ $=1,187)$. V štatisticky významnej dimenzii Ú - úlohy, na hladine 0,000 s vel'mi vysokou signifikanciou, sme identifikovali vo všetkých 7., 8. a 9. ročníkoch najnižšie hodnoty priemeru (najmenej frekvencií), kde pre 7. ročník je najnižšie priemerné skóre $-\mathrm{AM}=$ $1,24(\mathrm{SD}=1,022), 8$. ročník $-\mathrm{AM}=0,74(\mathrm{SD}=0,771)$ a 9. ročník s najmenším priemerom $-\mathrm{AM}=0,96(\mathrm{SD}=1,027)$. Z výsledkov záverečného celkového skóre vyplýva, že vedúce postavenie z ročníkov zastupuje v postupnosti najskôr 7. ročník s najvyššie dosiahnutým priemerným skóre $-\mathrm{AM}=13,91$ ( $\mathrm{SD}=13,91)$, potom 8. ročník s priemerom - $\mathrm{AM}=12,96(\mathrm{SD}=3,020)$ a posledné umiestnenie má 9. ročník s najnižším priemerným skóre $-\mathrm{AM}=$ 12,63 (SD = 3,312). Uvádzali sme štatisticky vel'mi vysoko signifikantné výsledky na hladine významnosti 0,001 . Na základe zistení môžeme konštatovat', že aj hypotéza H 1.3 sa potvrdila.

- H 1.4 Predpokladali sme, že počet žiakov v triede sa premieta do úrovne akceptovania prístupov inklúzie vo výučbe.

$\mathrm{Z}$ dôvodu overenia vzt'ahu medzi počtom žiakov $\mathrm{v}$ triede a hodnotami skóre jednotlivých dimenzií sme použili Pearsonov korelačný koeficient $\mathrm{r}(\mathrm{N}=428)$. Prostredníctvom štatistickej metódy pre analýzu metrických údajov sa nám podarilo identifikovat' štatisticky významný vzt’ah medzi počtom žiakov v triede a dvomi dimenziami A - angažovanie, S - sebahodnotenie. Štatistická významnost' sa potvrdila tak isto aj v celkovom skóre. Vyhodnotením získaných údajov potvrdzujeme, že sme zaznamenali štatisticky významné výsledky medzi dvoma premennými celkovo v troch hladinách. $\mathrm{Na}$ hladine $-0,127$ s koreláciou vysoko signifikantnou na úrovni $\leq 0,01$ sa nám potvrdil štatisticky významný vzt'ah medzi počtom žiakov $\mathrm{v}$ triede a hodnotou skóre 
v dimenzii A - angažovanie. Druhá hladina korelácie je rovnako vysoko signifikantná na úrovni $\leq 0,01$ s hodnotou $-0,229$, čo znamená potvrdenie štatisticky významného vzt’ahu medzi premennými počet žiakov v triede a hodnota skóre v dimenzii S sebahodnotenie. Posledná, štatisticky významná hladina korelácie signifikantná na úrovni $\leq 0,05$ s číselným vyjadrením $-0,096$ potvrdzuje štatisticky významný vzt’ah medzi počtom žiakov $\mathrm{v}$ triede a hodnotou celkového skóre. Zo získaných údajov konštatujeme, že všetky štatisticky významné korelácie nadobudli zápornú hodnotu a blížia sa $\mathrm{k}$ hodnote -1 , najväčšmi dimenzia $\mathrm{S}-$ sebahodnotenie, tzn. že medzi porovnávanými premennými, teda počtom žiakov $\mathrm{v}$ triede a hodnotou skóre $\mathrm{v}$ dimenziách $\mathrm{A}$ angažovanie, $\mathrm{S}$ - sebahodnotenie a $\mathrm{v}$ celkovom skóre je tesnejší vzt’ah. $Z$ dôvodu záporného korelačného koeficientu vyjadruje, že medzi porovnávanými premennými je opačný vzt’ah, a to ten, že vysokým hodnotám jednej premennej sú zodpovedajúce skôr nižšie hodnoty druhej premennej a opačne. $Z$ toho vyplýva nasledovné konštatovanie, že čím je v triede väčší počet žiakov, tým je menšie aktívne angažovanie sa žiakov vo vlastnom učení sa a znižuje sa sebadôvera, sebarealizácia a sebahodnotenie podporujúce výkon každého žiaka, čo má vplyv aj na celkovú úroveň dodržiavania podmienok inklúzie vo výchovno-vzdelávacom procese. Sme toho názoru, že predpoklad efektívnejšieho uplatňovania aktívneho angažovania sa žiakov vo svojom učení sa a podporovaním sebadôvery, sebarealizácie a sebahodnotenia podporujúceho výkon každého žiaka je tým väčší, čím bude dodržiavaný menší počet žiakov $\mathrm{v}$ triede. Zo získaných výsledkov môžeme $\mathrm{v}$ závere konštatovat', že pri overovaní vzt’ahu medzi počtom žiakov v triede a hodnotami skóre jednotlivých dimenzií sme identifikovali štatisticky významný vzt’ah medzi počtom žiakov $\mathrm{v}$ triede a dimenziami A - angažovanie, $\mathrm{S}$ - sebahodnotenie, ale aj v celkovom skóre. V dôsledku nameraných hodnôt prijímame hypotézu 1.4, ktorá sa nám potvrdila.

- H 1.5 Predpokladali sme, že nezistíme signifikantné medzipohlavné rozdiely, podla ktorých by sa mala významne líšit' kvalita podmienok inklúzie $\mathrm{v}$ triede medzi chlapcami a dievčatami.

Rozdiely medzi žiakmi podla pohlavia sa overovali pomocou Studentovho t-testu, ktorý umožňuje porovnávat' priemery dvoch skupín. Na základe výsledkov t-testu môžeme konštatovat', že sa potvrdilo diferencovanie medzi chlapcami a dievčatami a zaznamenali sme medzi nimi štatisticky významné rozdiely iba v jednej položke. Medzi chlapcami a dievčatami bol štatisticky významný rozdiel v odpovediach na otázky týkajúce sa dimenzie Obohatenie. Priemerné skóre u dievčat bolo významne vyššie - AM $=16,45(\mathrm{SD}=3,518)$ ako u chlapcov $\mathrm{AM}=14,92(\mathrm{SD}=3,467)$. Položka Obohatenie je na hladine významnosti $0,000(\leq 0,001)$, to značí že ide o vel’mi vysoko signifikantnú premennú. $Z$ uvedeného dôvodu hovoríme o vysokej miere štatistickej významnosti. 
Pri ostatných dimenziách sa chlapci a dievčatá štatisticky významne nelíšili. V zist'ovaní rozdielov medzi žiakmi podl'a pohlavia nám z výsledkov vyplynulo, že u dievčat podiel'ajúcich sa na výskume sa prejavila častejšia miera Obohatenia zo sledovaných dimenzií oproti chlapcom. Skonštatovali sme, že kritérium pohlavia v skóre dotazníka sa potvrdilo iba v prípade tejto jednej položky. Myslíme si, že to súvisí práve s rozdielmi medzi pohlaviami v tom zmysle, že pri začatí obdobia puberty pohlavné hormóny zmenia predovšetkým správanie. Dievčatá sú viac empatickejšie, starostlivejšie, dôslednejšie, súcitnejšie, majú lepšiu verbálnu pamät', sú viac spoločensky aktívnejšie a viac komunikujú. Chlapci majú zmysel pre orientáciu, pribúda im sila, chut' riskovat', ale horšie je to už s trpezlivost'ou a s vyjadrovaním emócií. Práve z uvedených dôvodov môžu byt' odlišnosti medzi žiakmi využívané ako zdroj, vzájomné obohatenie vyučovania a učenia viac prospešné pre dievčatá, ako pre chlapcov. Z uvedených výsledkov nám vyplýva, že u dievčat podiel'ajúcich sa na výskume sa prejavila častejšia miera Obohatenia zo sledovaných dimenzií oproti chlapcom. Je potrebné skonštatovat', že kritérium pohlavia v skóre dotazníka sa potvrdilo len v prípade tejto jednej položky. Zo získaných výsledkov výskumného šetrenia môžeme konštatovat', že sa hypotéza H 1.5 potvrdila.

Napriek istým rozdielom celkových výsledkov (ktoré nepresiahli skóre jedného intervalu) sa nám preukázala závislost' medzi jednotlivými premennými, v dôsledku čoho môžeme skonštatovat', že sa nám predpokladaná hypotéza $\mathbf{H} 1$ potvrdila.

\section{Možnosti uplatnenia výsledkov výskumu vpedagogickej teórii a odporúčania pre pedagogickú prax}

Uvedomujeme si, že výsledky nášho výskumného šetrenia nie je možné celkovo zovšeobecnit'. Stanovené hypotézy sa potvrdili pre vybraný súbor skúmaných osôb, ktorý bol vybraný zámerne, nie však s ciel'om uskutočnit' reprezentatívne štatistické zistenie. $\mathrm{Na}$ základe teoretických východísk a empirického spracovania riešenej problematiky navrhujeme pre zdokonalenie pedagogickej teórie i edukačnej praxe, ako aj pre d'alšie výskumné bádanie v oblasti pedagogiky, nasledujúce odporúčania:

- Nami použité výskumné metódy pozorovania a dotazníka s vlastným návrhom výskumných nástrojov, a to pozorovacieho hárku Dodržiavanie podmienok / princípov inklúzie vo výchovnovzdelávacom procese spolu s kl'účovou pozorovacou analytickou schémou vyučovacej hodiny a dotazníka určeného žiakom Podmienky inklúzie vo výchovno-vzdelávacom procese môžu byt' nápomocné učitel'om pri snahe odhalit' stav žiackych vnímaní podmienok inklúzie v triede a podporit' rešpektovanie a aplikovanie princípov inklúzie učitel'mi do výchovno-vzdelávacieho procesu. Preto ich odporúčame implementovat' do vyučovania.

- Domnievame sa, že sprostredkovaním našich výsledkov predmetnej štúdie otvoríme možnosti novému a doposial' málo prebádanému 
východisku zvyšovania kvalít podmienok inklúzie žiaka v rámci školy bežného typu z aspektu diverzity školskej triedy.

- Výsledky zrealizovaného výskumu môžu byt' inšpiratívnym východiskom pri aplikácii d'alších príbuzných výskumov alebo pri komparácii nových zistení s výsledkami iných výskumov.

- Podl'a nášho názoru absentuje skvalitnenie pregraduálnej i postgraduálnej prípravy učitel'ov, ktorá by sa nezameriavala výlučne na intaktnú populáciu. $\mathrm{V}$ ponuke pedagogických fakúlt by sa malo vytvorit' celoplošné vzdelávanie pre zainteresovaných pedagogických pracovníkov, a to s ciel’om získat' tzv. minimum kompetencií pedagóga pre inkluzívnu prax. Vzniklo by tak jedno z východísk pre zlepšenie procesu realizácie princípov inkluzívnej pedagogiky v praxi.

- Zmena tradičného, zaužívaného spôsobu vyučovania musí predovšetkým vychádzat' z osobného záujmu učitel'a a z pochopenia filozofie inkluzívneho vzdelávania žiakov (školy pre všetkých) v podmienkach diverzity školskej triedy. Pre podporu tejto zmeny by bolo vhodné pre učitel'ov organizovat' pravidelné školenia, prednášky, semináre či vzdelávacie kurzy, v ktorých by dostávali možnost' oboznamovat' sa s najnovšími poznatkami z oblasti výchovy a vzdelávania s filozofickým pozadím inklúzie a tiež so špeciálnymi spôsobmi ich zavádzania do praxe.

- Inovatívne trendy sa do nášho praktického školského prostredia implementujú z časového hl'adiska dlhšie časové obdobie, preto je v prvom rade na samotných riaditel'och a vedení škôl, aby iniciovali snahu podpory inovácie svojich tradičných zaužívaných postupov vo výchovno-vzdelávacom procese, apelovali na učitel'ov svojim vlastným príkladom a frekventovane zapájali samotnú školu do aktuálnych výskumných šetrení. Pretože najpodstatnejším faktorom celkového úspechu inklúzie je prístup školy a jej pedagogických pracovníkov.

- Sme zástancami individuálneho a humanistického prístupu $\mathrm{k}$ žiakovi, preto podl'a nášho názoru je v prvom rade nevyhnutné zmenit' postoj učitel'ov k žiakom, ktorí by mali vychádzat' predovšetkým z požiadaviek a jednotlivých potrieb samotných žiakov, čím by postupne spoznávali ich individuálne osobitosti. Iba týmto spôsobom dokážu podporovat' svoju vieru, že ako žiaci intaktní, tak aj žiaci so špeciálnymi výchovno-vzdelávacími potrebami patria do tej istej triedy, a teda dokážu prijat' každého žiaka bez rozdielu. Načrtnutú problematiku je ale potrebné vnímat' $\mathrm{v}$ širšom kontexte.

Uvedený náčrt odporúčaní by mohol pozitívne prispiet' k celkovému zvyšovaniu dosahovaných výsledkov na našich základných školách a eliminovat' možnost' neúspechov učitel'ov vo vlastnej pedagogickej činnosti, ako aj žiakov $\mathrm{v}$ ich vzdelávaní. Jedným z podporných opatrení je zabezpečenie väčšej informovanosti širšej odbornej i laickej verejnosti o nevyhnutnosti inkluzívnej edukácie. Pri participovaní vyššie uvedených odporúčaní sme vychádzali práve zo skutočnosti, že teoretické spracovanie 
problematiky a výsledky získané empirickou sondážou obohatia spomínanú verejnost'.

\section{Bibliography}

BILLINGSLEY B. S. - BROWNELL, M. T. - ISRAEL M. - KAMMAN, M. L. 2013. A Survival Guide for New Special Educators. San Francisco: Jossey-Bass. ISBN 978-1-118-09568-3.

DUCHOVICOVA, J. 2013. Ponatie diversity v skolskom prostredi a aspekty pedagogickej diagnostiky $\mathrm{v}$ kontexte ziackej diversity. In Duchovicova, J. kol.: Diverzita skolskej populacie ako objekt pedagogickej vedy. Nitra: PF UKF. pp. 20-95. ISBN 978-80-558-0528-3.

DUCHOVICOVA, J. 2012. Diverzita skolskej populacie jako objekt pedagogickej vedy. In Duchovicova, J. a kol: Diverzita v edukacii. Nitra: PF UKF. ISBN 978-80-558-0223-7.

HUNT, N. - MARSHALL, K. 2012. Exceptional Children and Youth. 5th ed., United States: Wadsworth Cengage Learning. ISBN 978-1-133-30742-6.

HAJKOVA, V. - STRNADOVA, I. 2010. Inkluzivni vzdelavanii. Praha: Grada. ISBN 978-80-247-3070-7.

KASIKOVA, H. - STRAKOVA, J. (eds.). 2011. Diverzita a diferenciace v zakladnim vzdelavani. 1. vyd. Praha: Karolinum. ISBN 978-80-246-1911-8. KOMORA, J. - POLAKOVICOVA, R. 2013. Akceptacia diverzity skolskej triedy ako fundament zvysovania urovne inkluzie vo vyucovacom procese. In Duchovicova, J. a kol.: Diverzita skolskej populacie ako objekt pedagogickej vedy. Nitra: UKF. pp. 93-111. ISBN 978-80-558-0528-3.

KOMORA, J. - POLAKOVICOVA, R. 2013. Diverzita skolskej triedy v kontexte inkluzivneho vzdelavania ziackej populacie. Nitra: UKF. ISBN 978-80-558-0379-1.

KVETONOVA, L. - STRNADOVA, I. - HAJKOVA, V. 2012. Cesty k inkluzi. Praha: Karolinum. ISBN 978-80-246-2086-2.

LECHTA, V. (ed.) 2012. Inkluzivna edukacia ako multidimenzionalny vychovny problem. Bratislava: IRIS. ISBN 978-80-89256-82-2.

MEIJER, C. - SORIANO, V. - WATKINS, A. 2003. Special Needs Education in Europe. Thematic publication. European Agency for Development in Special Needs Education: Eurydice. ISBN 87-90591-77-1.

PINTES, G. 2014. Svetonazorove a konceptualne vychodiska edukacnej diverzity. Nitra: UKF. ISBN 978-80-558-0585-6.

POLAKOVICOVA, R. 2011. Diverzita skolskej triedy v kontexte inkluzivneho vzdelavania ziakov so specialnymi vychovno-vzdelavacimi potrebami. Dizertacna praca. Nitra: UKF.

SEIDLER, P. - BELIKOVA, V. - DUFEKOVA, A. 2013. [In]akosti v terciárnom vzdelávaní. Nitra: PF UKF. ISBN 978-80-558-0477-4.

SEIDLER, P. - KURINCOVA, V. 2005. Inakosti V edukacnom prostredi. Nitra: PF UKF. ISBN 80-8050-839-9.

SEIDLER, P. - KURINCOVA, V. - KOMORA, J. 2008. Cesty k inkluzii. Nitra: KPg PF UKF. ISBN 978-80-8094-446-9.

SLEZAKOVA, T. 2008. Preparation of a disabled child for entering the school in conditions of an ordinary nursery school. In The New educational Review. ISSN 1732-6729, Vol. 15, No. 2, pp. 129-135. 
STEVENS-SMITH, D. - WARNER, M. - PADILLA, M. 2014. The changing face of public education: the process of „revisioning“ elementary teacher preparation programs. In Journal of cultural diversity. ISSN 10715568, Vol. 21, No. 3, pp. 108-111.

ZILCHER, L. 2013. Analyza pouzivanych inkluzivne didaktickych strategii v CR a USA. Usti nad Labem: Univerzita J. E. Purkyne. ISBN 978-80-7414680-0.

PaedDr. Renáta Polakovičová, PhD.

Constantie the Philosopher University

Faculty of Pedagogy, Department of Pedagogy

Dražovská cesta 4, 94974 Nitra

Slovakia

rpolakovicova@ukf.sk 